\title{
A Rare Cause of Acute Urinary Retention: Urethral Caruncle
}

\author{
Nadir Bir Akut Üriner Retansiyon Sebebi: Üretral Karünkül
}

\author{
(1) Fatih Akdemir \\ Samsun Terme State Hospital, Clinic of Urology, Samsun, Turkiye
}

\begin{abstract}
A urethral caruncle is a benign tumor formation in the vascular structure originating from the posterior wall of the external urethral meatus primarily occurring in postmenopausal women. A vesical globe was identified in a 71-year-old patient admitted to our outpatient clinic with the complaints of vaginal bleeding and inability to urinate. Vaginal examination revealed a $2.5 \times 2.5 \mathrm{~cm}$ urethral caruncle. The patient's bladder was emptied via the insertion of a $16 \mathrm{~F}$ urethral catheter. Caruncle excision was performed, and the patient was started on local estrogen therapy and followed up.
\end{abstract}

Keywords: Urethra, Caruncle, Vesical globe

$\ddot{0 z z}$

Üretral karünkül genellikle postmenapozal dönemdeki kadınlarda eksternal üretral meanın arka duvarından kaynaklanan vasküler yapıda benign bir tümöral oluşumdur. Polikliniğimize idrar yapamama ve vajinal kanama şikayeti ile başvuran 71 yaşındaki hastada glob vezikale tespit edildi. Vajinal muayenesi esnasında 2,5×2,5 cm boyutlarında üretral karünkül tespit edilen hastaya $16 \mathrm{~F}$ üretral kateter yerleştirilerek mesane boşaltıldı. Karünkül eksizyonu yapılan hasta, lokal östrojen tedavisi başlanarak takibe alındı.

Anahtar Kelimeler: Üretra, Karünkül, Glob vezikale

\section{Introduction}

Urethral caruncle is a lesion that is generally seen in postmenopausal women. It originates from the posterior wall of the urethra and protrudes from the external urethral meatus. These lesions have high visibility and are usually smaller than 1 $\mathrm{cm}$ (1). They contain loose vascular connective tissues covered by hyperplastic urothelial and squamous and flat epithelial cells. Histologically, depending on the state of inflammation, vascularity, and fibrosis, there are three subtypes of urethral caruncle; papillomatous, angiomatous, and granulomatous. Despite being asymptomatic when small, large caruncles may cause bleeding and difficulty in urination. Although the etiology is not completely known, hypoestrogenemia is presumed to be effective and positive results can be obtained with estrogen replacement therapy or local estrogens (2).

\section{Case Presentation}

A 71-year-old female patient was admitted to our outpatient clinic with the complaints of vaginal bleeding and inability to urinate for the last 10 hours. Physical examination revealed a vesicle globe. During the insertion of a transurethral catheter, a dark red $2.5 \times 2.5 \mathrm{~cm}$ polypoid lesion of a vascular structure protruding out of the urethral meatus was observed. It contained sites of bleeding foci and had an overlying hematoma (Figure 1). The bladder was emptied of approximately 700 cc urine using a $16 \mathrm{~F}$ catheter. The patient's history revealed a gradual reduction in urine flow for the last three years and the presence of blood stains on her underwear over the past week. In the constructed ultrasonography, no pathology was observed in the bladder but a grade 4 hydronephrosis was identified in the left kidney. Computed tomography showed grade 4 hydronephrosis in the left kidney (Figure 2). The level of estrogen was determined to

Correspondence: Fatih Akdemir MD, Samsun Terme State Hospital, Clinic of Urology, Samsun, Turkiye

Phone: +90 5384040494 E-mail: nfatihakdemir@hotmail.com 0RCID-ID: orcid.org/0000-0003-1794-211X

Received: 26.07.2017 Accepted: 22.10.2017

Cite this article as: Akdemir F. A Rare Cause of Acute Urinary Retention: Urethral Caruncle. J Urol Surg 2018;5(3):209-211.

๑Copyright 2018 by the Association of Urological Surgery / Journal of Urological Surgery published by Galenos Publishing House. 


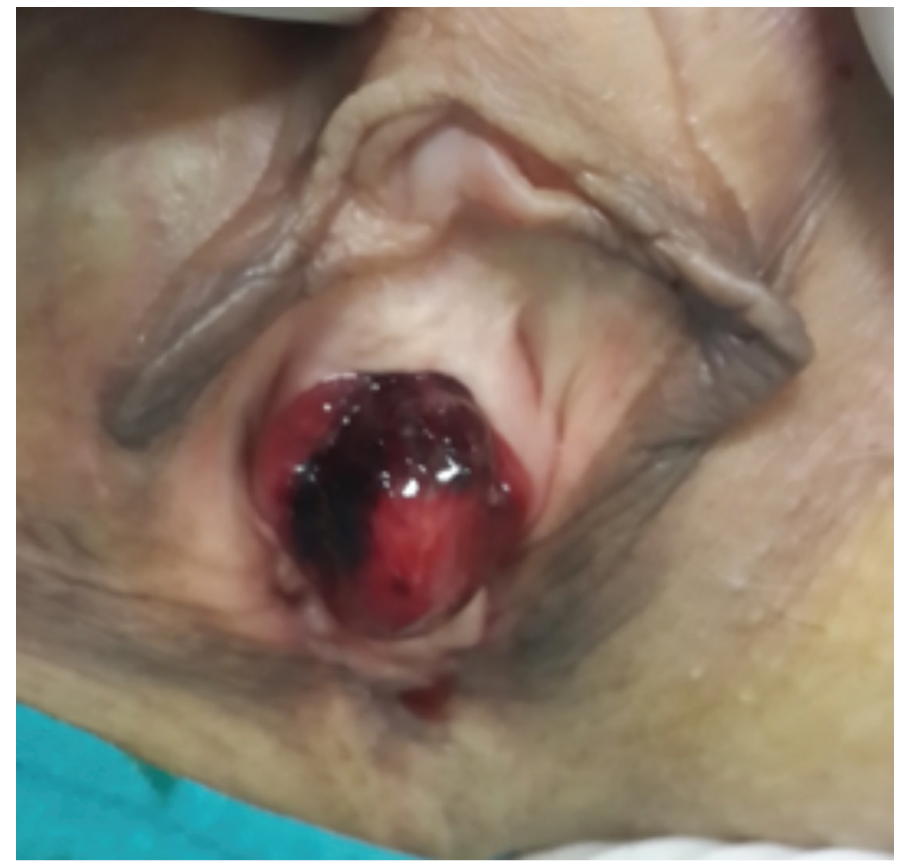

Figure 1. A dark red polypoid lesion with hematoma foci of the vascular structure outside the urethral meatus

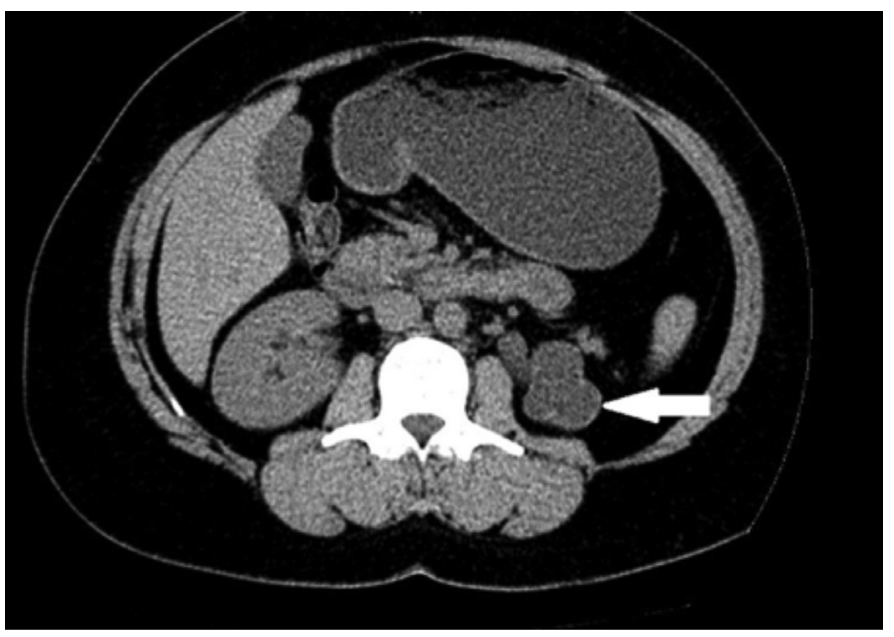

Figure 2. Grade 4 hydronephrosis image in the left kidney (arrow)

be $5 \mathrm{pg} / \mathrm{mL}$. The patient was scheduled for surgical excision of the urethral caruncle. Following preparations and obtaining the patient's informed consent, diagnostic cystoscopy was performed under general anesthesia. There were no other lesions in the bladder; however, common trabeculations, cellulite, and small diverticula were observed. Following the insertion of a $16 \mathrm{~F}$ transurethral catheter, the urethral caruncle was excised and the urethral mucosa was sutured to the meatus. During this procedure, it was observed that the patient's vagina and urethra were atrophic and fragile. After the operation, the patient was started on local estrogen therapy. No postoperative complication occurred. The catheter was removed five days after the operation and the patient was able to urinate without difficulty. The patient was followed up for the detection of recurrence. Histopathological examination of the mass revealed urethral caruncle.

\section{Discussion}

The most common benign tumor in female urethra is a urethral caruncle. Although it is usually seen in the postmenopausal period, it can also develop at younger ages. Urethral caruncles are reddish, raspberry-like, hemorrhagic lesions usually smaller than $1 \mathrm{~cm}$. Small-sized caruncles are usually asymptomatic; however, when they grow, they may cause urinary retention. The malignancy rate has been reported as 1.6\% $(2,3,4)$.

Although caruncles are usually benign, they should be surgically excised and histopathologically examined since they may be the indicators of lymphoma, clitoral venous thrombosis, urethral thrombosis, pseudoneoplastic lesions, urethral polyps, malign melanoma, intestinal heterotypic, angiomatous lesions, and diastolic urethral stenosis $(5,6,7,8,9,10,11)$. Microscopically, a caruncle is surrounded by an epithelial layer and consists of connective tissues formed by dense inflammatory cells, in particular the polymorphonuclear cells. In addition, reactive patterns, such as fibrocapillary proliferation (granulomatous), hypervascularity (angiomatous), epithelial hyperplasia (papillamatous), or intestinal metaplasia (mucinous), may also be observed (12).

Although urethral caruncles do not usually result in complaints other than cosmetic distress, they sometimes lead to bleeding observed as blood stains on underwear, painful urination with an intermittent split stream, and acute urinary retention (13). In addition to these conditions, the differential diagnosis of a urethral caruncle should include the elimination of other diseases that cause paraurethral masses, such as senile urethritis, skeletal abscess, infected urethral diverticulum, ectopic ureterocele, Gartner's duct cyst, residual Mullerian cyst, vaginal wall cyst, and urethral-vaginal neoplasms. It has been reported that small urethral caruncles can be treated with topical estrogen, antiinflammatory treatment, and cryoablation. Large caruncles blocking the urinary flow should be surgically excised (14). Biopsy and histopathological examination are the only way of excluding the possibility of malignancy irrespective of the size of the mass. Furthermore, in patients with estrogen deficiency, recurrence may be observed albeit rare and after a long period.

In conclusion, despite usually being considered as benign formations, urethral caruncles do require a histopathological examination for a definitive diagnosis. The elimination of estrogen deficiency, particularly in postmenopausal patients, would also prevent future complications. 


\section{Ethics}

Informed Consent: It was obtained.

Peer-review: Externally peer-reviewed.

Financial Disclosure: The author declared that this study received no financial support.

\section{References}

1. Hertig AT, Gore $H$, Sect $X, F A S C$. 33. Tumors of the vulva, vagina and uterus. Washington, DC, 1960, pp, 49.

2. Everett HS, Williams TJ. Campbell and Harrison Urology. 3rd ed. Saunders Co; Urology in the female; Philadelphia, PA, 1970, pp, 1957-1970.

3. Hees E. Primary carcinoma of the female urethra. Penn Med J 1945;48:11501154.

4. Walther HWE. Caruncle of the female urethra. Penn Med J 1943;50:308388.

5. Urakami S, Igawa $M$, Shiina $H$, Ishibe T. Urethral caruncle with coexistence of intestinal heterotopia: A case report. Int Urol Nephrol 1997;29:341-344.

6. Becker LE. Urethral caruncle: A herald lesion for distal urethral stenosis? J Natl Med Assoc 1975;67:228-230.
7. Young RH, Oliva E, Garcia JA, Bhan AK, Clement PB. Urethral caruncle with atypical stromal cells lymphoma or sarcoma - a distinctive pseudoneoplastic lesion of females. A report of six cases. Am J Surg Pathol 1996;20:11901195.

8. Fernández Arjona M, De castro Barbosa F, Cortés Aranguez I, Pop B, Perandones Fernández C, Ladrón Gil C. Female urethral caruncle. A thrombosis of the dorsal venous complex? Actas Urol Esp 1998;22:443-445.

9. Lee WH, Tan KH, Lee YW. The aetiology of postmenopausal bleeding-a study of 163 consecutive cases in Singapore. Singapore Med J 1995;36:164-168.

10. Lopez Jl, Angulo JC, Ibanez T. Primary malignant melanoma mimicking urethral caruncle. Case report. Scand J Urol Nephrol 1993;27:125-126.

11. Kaneko G, Nishimoto K, Ogata K, Uchida A. A case of intraepithelial squamous cell carcinoma arising from urethral caruncle. Can Urol Assoc J $2011 ; 5: 14-16$

12. Çimentepe E, Bayrak O, Unsal A, Koç A, Ataoğlu O, Balbay MD. Urethtral adenocarcinoma mimicking urethral caruncle. Int Urogynecol J 2005;17:9698.

13. Tanagho EA, Brant WO, Lue TF. Disorders of the female urethra. In: Tanagho EA, McAnnich JW. Smith's General Urology. 17th ed. San Francisco, McGrawHill, 2008, pp, 638-644.

14. Rovner E. Bladder and Urethral diverticula. In: Wein AJ, Kavoussi LR, Novick AC, Partin AW, Peters CA. Campbell-Walsh Urology 9th ed. Philadelphia, Saunders, 2007, pp, 2361-2391. 